\title{
EFFECT OF DRYING PROCESSES ON BIOCHEMICAL CONTENTS OF SPIRULINA PLATENSIS AS A PROTIEN SOURCE FOR FISH DIET
}

\author{
Abou El-Kheir, W. S. ${ }^{(1)}$; Ibrahim, E.A. ${ }^{(2)}$; Abd El-Razek, A. B. ${ }^{(3)}$ \\ and Helal, A. M. ${ }^{(2)}$
}

1) Women's Collage for Arts, Science and Education, Ain Shams University

2) National Institute of Oceanography and Fisheries 3) Faculty of Agriculture, Ain Shams University

\begin{abstract}
The present work aimed at studying the effect of drying temperature on the biochemical contents of Spirulina platensis to choose the best temperature that can be used for drying without affecting its contents to be used as a fish diet, with a good quality, low price and to give the immunity to fish in fish farms. Open air and temperatures $\left(60^{\circ} \mathrm{C}\right.$ and $\left.120^{\circ} \mathrm{C}\right)$ were applied for drying Spirulina platensis. The alga was cultivated on large scale in concrete ponds $\left(25\right.$ and $\left.50 \mathrm{~m}^{3}\right)$ to be used as fish meal. The crude protein content of the dried matter in S. platensis biomass was 59.1, 63.2, and $64.8 \%$ in case of open air, $60^{\circ} \mathrm{C}$ and $120^{\circ} \mathrm{C}$ respectively. Also there are no significant differences measured of amino acids content on open air, $60{ }^{\circ} \mathrm{C}$ and $120{ }^{\circ} \mathrm{C}$. The nutritional value of protein is due to its amino acids contents which were of $49 \%, 49 \%$ and $50 \%$ for the dried matter at open air and $60^{\circ} \mathrm{C}$ and $120^{\circ} \mathrm{C}$ respectively. Also, the lipid contents, carbohydrates, fibers and ash were $0.74 \%, 20.78 \%, 0.18 \%$ and $8.8 \%$ respectively in open air, $0.78 \%, 18.9 \%$, $0.22 \%$ and $8.8 \%$ at $60^{\circ} \mathrm{C}$ and $0.94 \%, 19.74 \%, 0.12 \%$ and $9.0 \%$ respectively at $120{ }^{\circ} \mathrm{C}$. The results revealed that the concentrations of chemical contents (lipid, carbohydrates, fibers and ash) were higher at $120{ }^{\circ} \mathrm{C}$ than those at the other two procedures. The concentrations of crude protein $(64.8 \%)$ and amino acids $(50 \%)$ were also higher at $120{ }^{\circ} \mathrm{C}$. It was found that there is no difference between the three procedures of drying but drying at $120{ }^{\circ} \mathrm{C}$ saves time and therefore it is better to be used. Sixteen weeks of feeding was conducted to investigate the effect of fish meal replacement with Spirulina on


growth performance and body weight. About $20 \%$ increase of weight gain and with highly significant average daily gain 0.450 and 0.546 for diet1 (control) and diet 2 (Spirulina diet) respectively and feed conversion ratio were 1.189 and 1.333 for diet 1 (control) and diet 2 (Spirulina diet). The use of the harvested alga $S$. platensis was to solve the problem of availability as protein source not only as fish feed but also saving aquatic environment.

\section{INTRODUCTION}

Spirulina (Arthrospira) plate 1 is a filamentous cyanobacterium easily cultivated and cheaply recovered by filtration from the medium. Spirulina is an attractive source of protein, carbohydrates, lipids, chlorophyll, vitamins, amino acids and pigments that it can be used in food, feed, pharmaceutical use and cosmetic industries. Spirulina contains about $60 \%$ highly digestible protein, essential and non-essential amino acid, more beta carotene than any other whole food and it is rich in vitamin B, minerals, trace elements and enzymes. Spirulina is one of the most frequently used microalgae in aquatic animal feeds due to its high contents of protein, vitamins, essential amino acids, minerals, essential fatty acids and antioxidant pigments such as carotenoids (Nakagawa and Montgomery, 2007). High protein content of Spirulina as well as its well- balanced amino acid profile compared with other plant protein sources makes it as potential fish meal replacer in aquafeed formulation (Hanel et al. 2007)

Spirulina platensis is needed to be used on a large scale for commercial source of nutrients due to its high contents of amino acids, vitamins and high protein. Therefore it is needed to produce $S$. platensis as supplementary feed for fish. Zarrouk (1966), Costa et al. (2001), Soletto et al. (2004) and Feng 2 
and $\mathrm{Wu}(2006)$ were used different utilization purposes with different ratio of commercial nitrogen sources (urea, ammonium sulphate, human urine and nitrate) for Spirulina platensis production. Also El-Gamal (1998) produced protein and carbohydrates from Spirulina platensis cheaply cultivated on organic wastes supplemented by organic substrate molasses which stimulate the growth of this alga.

A great deal of researches has gone into methods of protecting the nutrients quality during the drying process. Freeze drying is the best way of drying but it is so expensive and complicated. Sun drying is the most popular among small producers, but requires a few precautions. Helene and Fabiola (2004) used a different process of drying as convective drying, freeze drying, infrared drying and spray drying. the biochemical and physical criteria of Spirulina platensis were studied and concluded that freeze drying showed the high retention of the analyzable protein and sugars. Abou El-Kheir et al. (2008) dried Spirulina in open air for 48 hours in shade and average temperature of $30-35{ }^{\circ} \mathrm{C}$ and produced Spirulina platensis powder with $61 \%$ protein and $5.28 \mathrm{~g} / 10 \mathrm{~g}$ amino acids. Jenny et al. (1997) the effect of three drying methods sun-drying, oven-drying and freeze-drying on nutritional composition of seaweed Sargassum hemiphyllum were studied and concluded that sun-dried seaweed has lower values of ash, mineral and total vitamin $\mathrm{C}$ contents than the other procedures. It was mentioned that this might be due to the leaching effect and long exposure time to air drying (sun-drying) although oven-dried seaweeds have the greatest nutrient losses, probably mainly due to 
the effect of high temperature during drying where it contained the highest mineral content.

Hilal and Ozlem (2014) reported another process for drying Spirulina platensis which was cultivated on chicken manure (by adding bicarbonate and urea). The biomass was dried at $50{ }^{\circ} \mathrm{C}$ for three days in incubator and the yield was preserved in the refrigerator also second drying process was applied at $65{ }^{\circ} \mathrm{C}$ for $45 \mathrm{~min}$.

Guo Yao (2012) studied the effect of different drying process on the quality of Spirulina platensis. Four approaches of drying process, including microwave drying, freeze drying and hot air drying were investigated by measuring organoleptic qualities. The results indicated that freeze drying produce a green powder with strong fishly smell similar to that of the used fresh alga.

Aji and Mohamad (2012) concluded that the higher operation temperature, the faster drying time, at thickness of Spirulina platensis mass ranging from 1-3 $\mathrm{mm}$ and operational temperature below $70{ }^{\circ} \mathrm{C}$. The quality of Spirulina platensis can fit the market requirements at $60-70{ }^{\circ} \mathrm{C}$ for drying time about 30-40 min. Tiburcio (2007) applied three low cost drying methods (sun and oven) to produce Spirulina platensis powder of optimal quality.

Phycocyanin is a natural blue pigment used in food and pharmaceutical industry and Spirulina platensis is an excellent source of phycocyanin. The protein fraction may contain up to $20 \%$ of phycocyanin which extracted from Spirulina platensis oven dried biomass ( Vonshake, 1997 and Wanida et al. 2014). Srada et al. (1999) studied a number of drying methods ( crossflow 
dried, spray dried and oven dried) for Spirulina platensis which resulted in approximately $50 \%$ loss of phycocyanin.

The main objective of this work is to study the effect of temperature for drying Spirulina platensis to choose the best temperature that saves its biochemical contents so that it can be used as fish diet in aquaculture.

\section{MATERIAL AND METHODS}

Strain: In the present study Spirulina platensis strain as shown in plate 1 was obtained from stock available in National institute of oceanography and fisheries, Hydrobiology department, Cairo, Egypt.

Culture condition: Experiments were done in open air under green house at Wadi El-Natroun area, Keram fish farm, Behira governerate, Egypt. Modified Zarrouk's medium (Abou ElKheir, et al. 2008) was used as a basic culture medium which prepared by dissolving the following major salts in $1 \mathrm{~m}^{3}$ underground water:

$10.0 \mathrm{~kg}$ commercial $\mathrm{NaHCO}_{3}, 250 \mathrm{~g}$ Urea, $50 \mathrm{ml} \mathrm{H} \mathrm{PO}_{4}, 0.5 \mathrm{~kg} \mathrm{~K} \mathrm{~K}_{2} \mathrm{SO}_{4}$, $1.0 \mathrm{~kg} \mathrm{NaCl}, 200 \mathrm{~g} \mathrm{MgSO}_{4}$. and $10 \mathrm{~g} \mathrm{FeSO}_{4}$ (all chemicals are of commercial grade)

Procedure: The experiments were carried out in concrete ponds containing $25 \mathrm{~m}^{3}$ and $50 \mathrm{~m}^{3}$ (plates 3 and 4) of modified Zarrouk medium. 3\% (v/v) inoculum of stock Spirulina platensis was added i.e for $1 \mathrm{~m}^{3}$ medium $30 \mathrm{~L}$ inoculum stock of Spirulina platensis was added. 
The measured temperature values were found to be between $25^{\circ} \mathrm{C}$ and 32 ${ }^{\circ} \mathrm{C}$ and the $\mathrm{pH}$ values were found to be between 8.5 and 9.5 in the cultivation medium.

The biomass of $S$. platensis as represented by $\mu \mathrm{g} / \mathrm{L}$ chlorophyll-a was measured daily by Eureka device Hydrolab Manta 2 water quality multiprob as shown in plate 2 .

Harvest: The alga was harvested after 12 day of growth from the medium solution by plankton cloth of $20 \mu \mathrm{m}$ mesh diameter (Plates 5 and 6)

Drying: The harvested biomass was subjected to air drying, oven drying 60 ${ }^{\circ} \mathrm{C}$ and oven drying $1 \curlyvee 0{ }^{\circ} \mathrm{C}$ for six hours to select the best procedure for saving the chemical contents of $S$. platensis to be used as fish diet.

\section{Biochemical contents:}

-Crude protein content was measured and calculated according to A.O.A.C. (2000) by micro-kjeldahl method.

-Phycocyanine was extracted and estimated Spectrophotometrically Seigelman and Kycia (1978)

-Carbohydrates was determined by the phenol sulphuric acid method as described by Dubois et al. (1993)

-Lipids and fibers were determined according to A.O.A.C. (1980).

Ash was determined according to A.O.A.C. (1984).

-Amino acids were measured according to official method of Analysis A.O.A.C. (2000)

Feeding experiments: The design of the experiment was carried out to investigate the effect of two types of diets on growth performance of Nile 
tilapia. Diet 1 (control) and Spirulina diet 2 (total replacement of fish meal by dried Spirulina platensis) for Tilapia feed. Nile tilapia fingerlings with initial weight average 5-6g were stocked at rate of $200 \mathrm{fish} /$ pocket. The experimental period was started from $4^{\text {th }}$ July 2015 to $4^{\text {th }}$ November 2015 and lasted for 120 days. According to the data of body weight, the parameters Average daily gain (ADG), Weight gain (WG) and Feed conversion ratio (FCR) were calculated according to (Osman et al., 2003)

\section{RESULTS}

Table 1 shows the chemical components and their concentrations in underground water used in the production of Spirulina platensis. The results revealed that the carbonate was below the detection limit. The concentrations of bicarbonate, calcium and magnesium were measured in $\mathrm{mg} / \mathrm{l}$ and the concentrations of ammonia, nitrite, nitrate and Orthophosphate were measured in $\mu \mathrm{g} / \mathrm{l}$.The hardness of water $\left(\mathrm{CaCO}_{3}\right.$ and $\left.\mathrm{MgCO}_{3}\right)$ was 48.1 and $29.3 \mathrm{mg} / \mathrm{l}$ respectively. The concentrations of limiting nutrients ammonia, nitrite, nitrate and orthophosphate were 282.9, 151.7, 365 and $178.2 \mu \mathrm{g} / \mathrm{l}$ respectively.

The chemical components for this type of water revealed that it was suitable for production of Spirulina platensis where all these concentrations were below the limit of production media for Spirulina platensis. 
J. Environ. Sci.

Institute of Environmental Studies and Research - AinShamsUniversity

Table 1 The main chemical contents and their concentrations inUnderground water

\begin{tabular}{|c|c|}
\hline Content & Concentration \\
\hline \hline Carbonate $\mathrm{mg} / \mathrm{l}$ & B.D.L \\
\hline Bicarbonate $\mathrm{mg} / \mathrm{l}$ & 215 \\
\hline Ammonia $\mu \mathrm{g} / \mathrm{l}$ & 282.9 \\
\hline Nitrite $\mu \mathrm{g} / \mathrm{l}$ & 151.7 \\
\hline Nitrate $\mu \mathrm{g} / \mathrm{l}$ & 365.0 \\
\hline Orthophosphate $\mu \mathrm{g} / \mathrm{l}$ & 178.2 \\
\hline Calcium $\mathrm{mg} / \mathrm{l}$ & 48.1 \\
\hline Magnesium $\mathrm{mg} / \mathrm{l}$ & 29.3 \\
\hline
\end{tabular}

B.D.L below detected limit

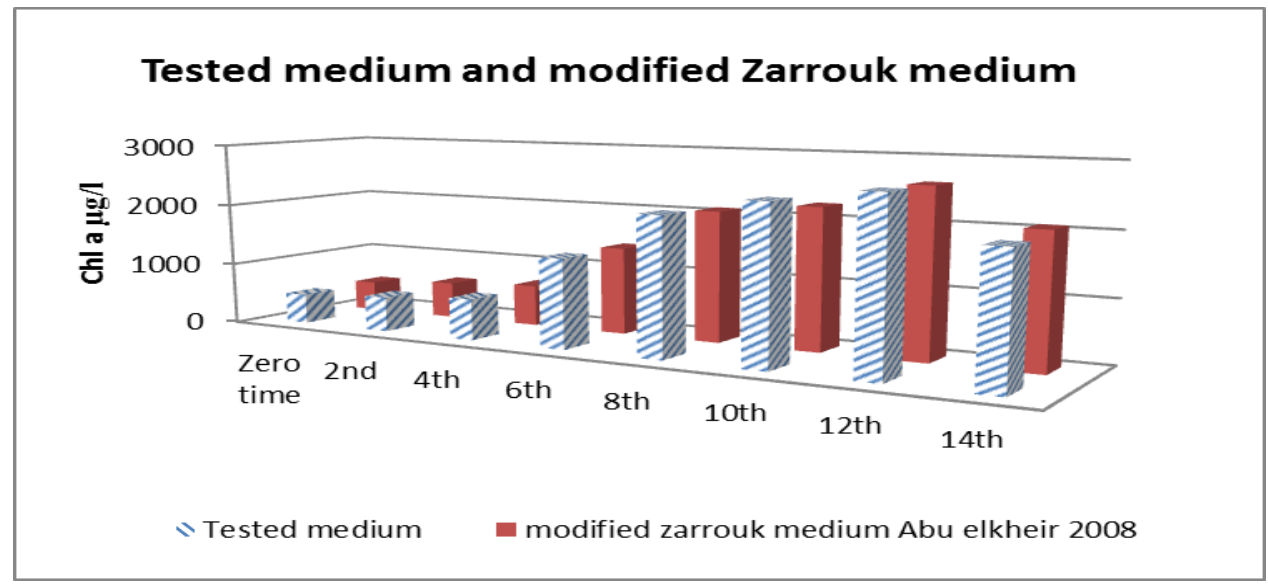

Figure 1. Concentration of $\mathrm{Chl}$ a $\mu \mathrm{g} / \mathrm{l}$ as a function of Spirulina platensis growth in tested medium and modified Zarrouk medium ( Abou-Elkheir 2008) incubation period for 14 days 
Results in Figure 1 revealed that the maximum value of chl-a was at $12^{\text {th }}$ day at when harvest started.

The results presented in Figure 2 revealed that phycocyanine concentrations have the highest value of $100 \%$ in fresh S. platensis and decreased with the increase of the drying temperature. In oven dried processing, the phycocyanin content was $64 \%$ and $38 \%$ at $60{ }^{\circ} \mathrm{C}$ and $120{ }^{\circ} \mathrm{C}$ respectively while in open air it was $86 \%$. There was considerable loss of phycocyanin in the dried samples.

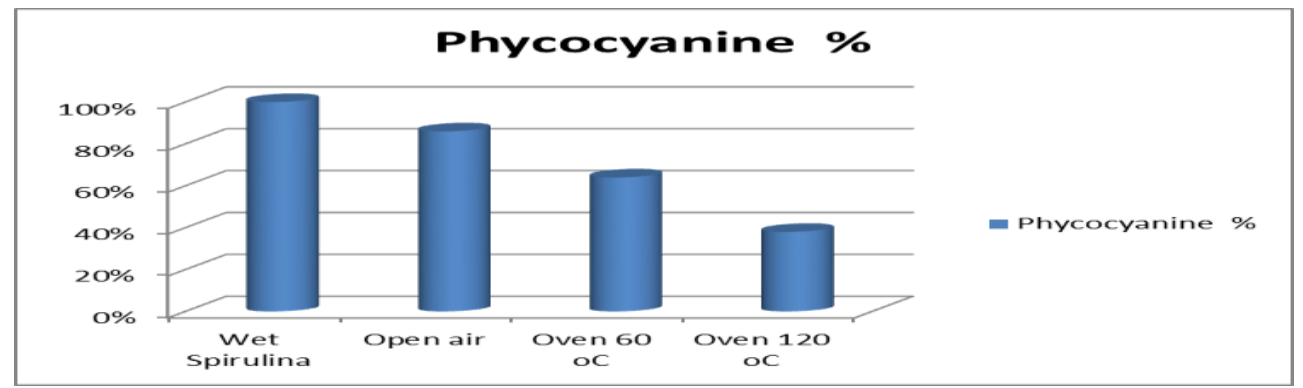

Figure 2: Effect of drying temperatures on the Phycocyanine \% extracted from S. platensis

The biochemical contents of $S$. platensis powder (crude protein, carbohydrates, lipids, ash, fibers and moisture) were detected by percentage (\%) as shown in Table 2, regarding the three drying processes. 
Table 3: Biochemical contents of S. platensis dried in open air, oven dry 60 ${ }^{\circ} \mathrm{C}$ and $120{ }^{\circ} \mathrm{C}$

\begin{tabular}{|c|c|c|c|c|c|c|}
\hline $\begin{array}{c}\text { Drying } \\
\text { processes }\end{array}$ & $\begin{array}{c}\text { Crude } \\
\text { Protein \% }\end{array}$ & Carbohydrates\% & $\begin{array}{c}\text { Lipids } \\
\text { \% }\end{array}$ & $\begin{array}{c}\text { Ash } \\
\text { \% }\end{array}$ & $\begin{array}{c}\text { Fibers } \\
\text { \% }\end{array}$ & $\begin{array}{c}\text { Moisture } \\
\%\end{array}$ \\
\hline Open air & 59.1 & 20.78 & 0.74 & 8.8 & 0.18 & 10.4 \\
\hline Oven $60 \mathrm{oC}$ & 63.20 & 18.9 & 0.78 & 8.8 & 0.22 & 8.10 \\
\hline Oven $120 \mathrm{oC}$ & 64.8 & 19.74 & 0.94 & 9.0 & 0.12 & 5.4 \\
\hline
\end{tabular}

The results in Table 3 revealed that the crude protein were 59.1, 63.2 and $64.8 \%$ at open air, $60{ }^{\circ} \mathrm{C}$ and $120{ }^{\circ} \mathrm{C}$ drying temperature respectively. Carbohydrates concentration $5.4 \%$. The protein contents slightly higher at $120{ }^{\circ} \mathrm{C}$. Carbohydrates values were $20.78,18.9$ and 19.74 as they slightly the same percent. lipid concentrations were $0.74,0.78$ and $0.94 \%$ at open air, 60 ${ }^{\circ} \mathrm{C}$ and $120{ }^{\circ} \mathrm{C}$ respectively, the results of lipids were low. The ash content $\%$ ranged from $8.8-9.0$ for the three types of drying. The fibers contents were $0.18,0.22$ and $0.12 \%$ at open air, $60{ }^{\circ} \mathrm{C}$ and $120{ }^{\circ} \mathrm{C}$ respectively.

The percentage of essential and non-essential amino acid contents of dried S. platensis in open air, $60{ }^{\circ} \mathrm{C}$ and $120{ }^{\circ} \mathrm{C}$ are shown in table 4. 
Table 4 :Hydrolyzed amino acid composition of $S$. platensis dried at open air, $60{ }^{\circ} \mathrm{C}$ and $120^{\circ} \mathrm{C}(\mathrm{mg} / \mathrm{g})$

\begin{tabular}{|c|c|c|c|c|}
\hline \multicolumn{2}{|r|}{ Amino acid } & \multicolumn{3}{|c|}{ Amino acids mg/g } \\
\hline & & Open air & 60 oC & 120 oC \\
\hline \multirow{8}{*}{ 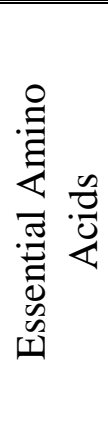 } & Leucine LEU & 4.22 & 4.19 & 4.34 \\
\hline & Isoleucine ILE & 2.76 & 2.69 & 2.81 \\
\hline & Phenylalanine PHE & 2.38 & 2.54 & 2.42 \\
\hline & Valine VAL & 3.27 & 3.24 & 3.39 \\
\hline & Therionine THR & 2.5 & 2.52 & 2.56 \\
\hline & Lysine LYS & 2.21 & 2.19 & 2.22 \\
\hline & Histidine HIS & 0.84 & 0.8 & 0.84 \\
\hline & Methionine & 1.09 & 1.05 & 1.04 \\
\hline \multirow{10}{*}{ 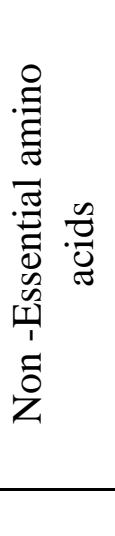 } & Aspartic ASP & 4.99 & 5.03 & 5.11 \\
\hline & Serine SER & 2.32 & 2.29 & 2.32 \\
\hline & Glutamic GLU & 7.61 & 7.67 & 7.98 \\
\hline & Proline PRO & 1.91 & 1.76 & 1.92 \\
\hline & Glycine GLY & 2.49 & 2.54 & 2.62 \\
\hline & Alanine ALA & 4.09 & 4.02 & 3.96 \\
\hline & Tyrosine TYR & 2.01 & 2.22 & 2.11 \\
\hline & Argnine ARG & 3.55 & 3.46 & 3.54 \\
\hline & Cystine CYS & 0.42 & 0.38 & 0.47 \\
\hline & TOTAL & 48.66 & 48.59 & 49.65 \\
\hline
\end{tabular}

The results of the total amino acids contents of $S$. platensis dry matter were $48.66,48.59$ and $49.65 \mathrm{mg} / \mathrm{g}$ in open air, $60{ }^{\circ} \mathrm{C}$ and $120{ }^{\circ} \mathrm{C}$ respectively.

The results in Table 4 showed the amino acids contents \% of dried Spirulina platensis in $120{ }^{\circ} \mathrm{C}$ was higher than that in open air or in $60{ }^{\circ} \mathrm{C}$ for all amino acids except phenylalanine, methionine, alanine, tyrosine and arginine were slightly lower. The highest values of essential amino acid were 
4.22, 4.19 and $4.34 \%$ is leucine LEU in open air, $60{ }^{\circ} \mathrm{C}$ and $120{ }^{\circ} \mathrm{C}$ respectively.

The highest values of non-essential amino acid (glutamic acid) were 7.61, 7.67 and $7.98 \%$ in open air, oven $60{ }^{\circ} \mathrm{C}$ and oven $120{ }^{\circ} \mathrm{C}$ respectively.

Table 5 :Growth performance of Nile tilapia fingerlings

\begin{tabular}{|c|c|c|c|c|c|}
\hline \multicolumn{7}{|c|}{ Growth performance } \\
\hline Diets & $\begin{array}{c}\text { Initial Body weight } \\
(\mathbf{g})\end{array}$ & $\begin{array}{c}\text { Final Body } \\
\text { weight }(\mathbf{g})\end{array}$ & $\begin{array}{c}\text { WG } \\
(\mathbf{g})\end{array}$ & $\begin{array}{c}\text { ADG } \\
(\mathbf{g})\end{array}$ & FCR \\
\hline $\begin{array}{c}\text { diet 1 } \\
\text { (control) }\end{array}$ & $4.763 \mathrm{a}$ & $58.763 \mathrm{~b}$ & $54.000 \mathrm{~b}$ & $0.450 \mathrm{~b}$ & $1.189 \mathrm{a}$ \\
\hline $\begin{array}{c}\text { diet 2 } \\
\text { (Spirulina) }\end{array}$ & $5.056 \mathrm{a}$ & $70.66 \mathrm{a}$ & $65.603 \mathrm{a}$ & $0.546 \mathrm{a}$ & $1.333 \mathrm{~b}$ \\
\hline SE & 0.110 & 0.712 & 0.627 & 0.005 & 0.011 \\
\hline $\operatorname{Pr}$ & 0.1345 & 0.0003 & 0.0002 & 0.0002 & 0.0228 \\
\hline
\end{tabular}

SE standard error Pr probability

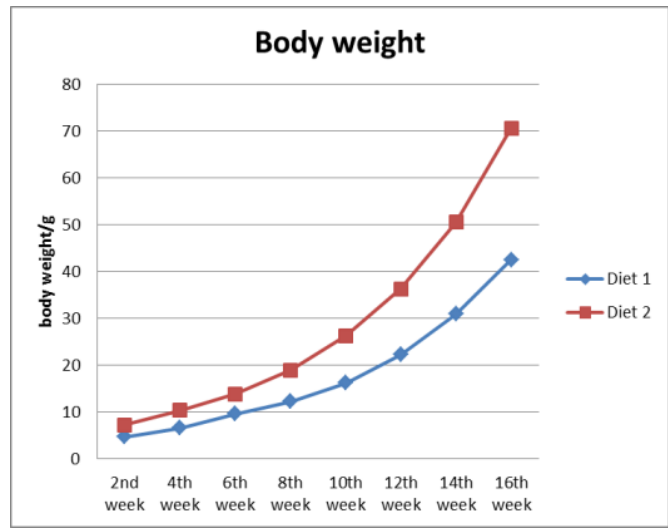

Figure 4: Body weight $\mathrm{g} /$ fish every 2 weeks for 16 weeks

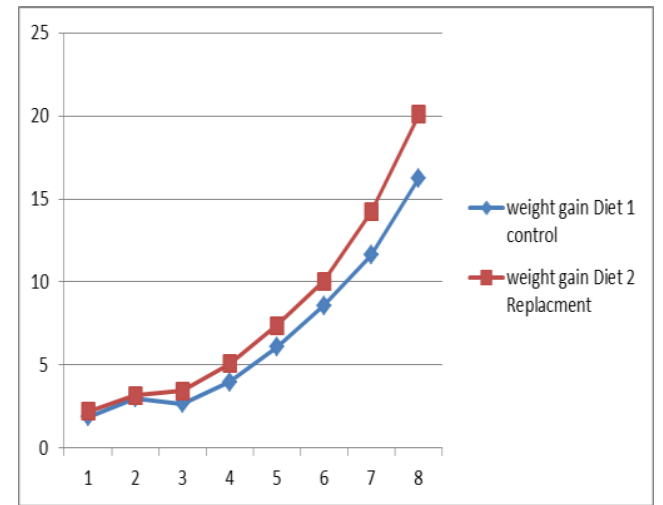

Figure 5 weight gain of the two groups fed on Diets 
The growth performance of Nile tilapia fingerlings fed on the experimental diets (control diet and Spirulina diet) is presented in Table 5. Table 5 shows that there was highly significant growth performance for the two types of diets. Results showed that the higher value of weight gain was 65.603 for group fed on diet 2(Spirulina diet) with total replacement of Spirulina platensis than that fed on diet 1(control). Also with higher average daily gain of 0.546 for the group that fed on diet 2 (Spirulina diet) was higher than that group fed on diet 1(control). Figures 4 and 5 show that the body weight and weight gain for the group of fish that fed on diet 2 were higher than the group fed on diet 1 (control) during the duration of the experiment.

\section{DISCUSSION}

The results of analysis in Table 1 revealed that the concentrations of the chemical components for the used underground water were suitable for production of Spirulina platensis where all these concentrations were below the limit of production media.

The recent researches aimed to change the source of water from distilled water as in Zarrouk medium to other available sources. There are different types of water can be used for production of Spirulina platensis starting from distilled water as in Zarrouk's medium (1966), fresh water as in Jorge et al., medium (2003), brackish water as in Richmond medium (1988) and alkaline water as Vonshake (1978), Aly (2000) and Goldstein (1986) media, Tolga (2007) studied the growth of Spirulina platensis using drinking water for preparation of Zarrouk medium, Abou El-Kheir et. al., (2008) used a boiled tap water for commercial production of Spirulina platensis, Fox (1999) and 
Sandeep et. al., (2015) used sea water for large scale production of $S$. platensis. All the above researches tried to adapt the growth of S. platensis by using to the available sources of water as cost effective.

The results presented in Table 2 revealed that phycocyanin concentration produced from the used dried S. platensis in open air, $60^{\circ} \mathrm{C}$ and $120{ }^{\circ} \mathrm{C}$ decreased with the increase of drying temperature, taking in consideration that phycocyanine concentration of $100 \%$ was in the fresh $S$. platensis sample. Therefore, fresh biomass is the best for phycocyanin content. Srada et. al. (1999) studied a number of drying methods for Spirulina platensis (crossflow dried, spray dried and oven dried) where phycocyanin loss was approximately 50\%.This results were not in agreement with the present study in case of open air dry and $60{ }^{\circ} \mathrm{C}$ where the loss of phycocyanin was $14 \%$ and $36 \%$ respectively but in agreement with that in $120{ }^{\circ} \mathrm{C}$ where the loss was $62 \%$.

The present results Table 3 revealed that the modified medium produce S. platensis containing a crude protein of $59.1 \%, 63.2 \%$ and $64.8 \%$ in open air, $60{ }^{\circ} \mathrm{C}$ and $120{ }^{\circ} \mathrm{C}$ respectively. These results were in agreement with the results obtained by Aly and Aumar (2003) and Abou El-kheir et. al. (2008) who obtained a crude protein from $S$. platensis ranged from $50-70 \%$ by using modified Zarrouk's medium by replacing other nutrients such as ammonium sulphate, potassium nitrate, urine and commercial fertilizers in the medium. Due to the quality of protein produced from Spirulina platensis, it is used as protein source in diets with different ratios. 
The valuable protein is due to its availability and proportion of amino acids (essential and non- essential). The term essential amino acid includes amino acids that are required for optimum growth of the heterotrophic organisms and the non-essential amino acids also important for growth but they can synthesize by heterotrophic organisms.

The present results showed that the values of amino acids were $49 \%$, $49 \%$ and $50 \%$ at open air , $60^{\circ} \mathrm{C}$ and $120{ }^{\circ} \mathrm{C}$ respectively which was in agreement with the results obtained by Dillon and Phan (1993) who reported that essential amino acids were $47 \%$ of protein and $50 \%$ total amino acids. Also Abou El-kheir et. al. (2008) reported that amino acids were 52\% of crude protein produced by using commercial medium. According to the used medium and its components, the change of proportion of amino acids and ratios of biochemical contents of $S$. platensis gave the high nutritional value of Spirulina compared with the other plant foods. The present results were in agreement with results obtained by Mepham (1997) and Abou El-kheir et. al. (2002) who reported that $S$. platensis was commercially productive alga which was a remarkable rich source of pigments and amino acids.

The results revealed that the growth performance of Nile tilapia fingerlings fed on diet 2 (Spirulina diet) with replacing S. platensis as a source of protein gave a highly significant increase in the weight gain and body weight with about $20 \%$ and an increase in food conversion ratio. So Spirulina can be used as a good replacer for fish as protein source. The results are in agreement with that obtained by Hanel et. al., (2007) who concluded that due to high protein contents of $S$. platensis and its essential amino acids 
makes it as potential fish meal (FM) replacer in aquafeed formulation. In the present study $S$. platensis was used as complete replacement for protein source which was in agreement with the results obtained by Dernekbasi et. al., (2010) and Tongsiri et. al., (2010) 


\section{Plates}
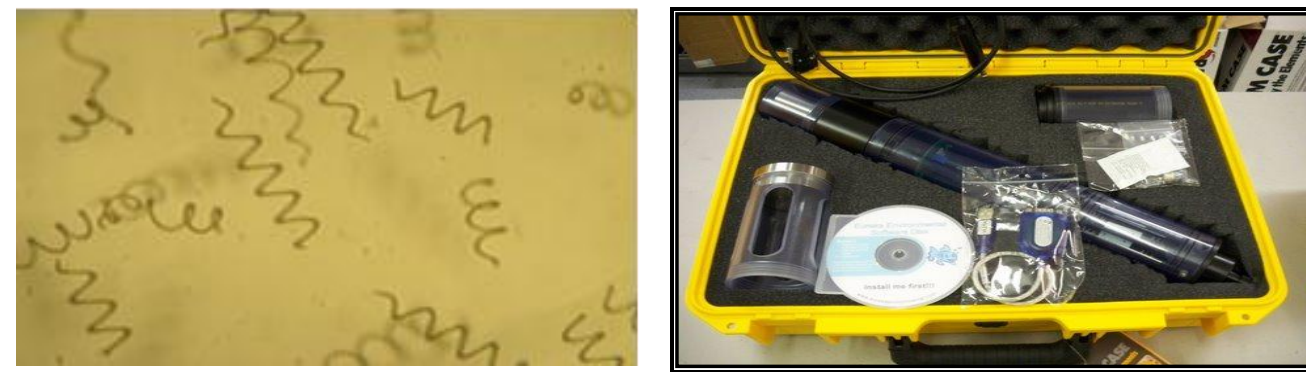

Plate 1 Spirulina platensis (Nords, Geitler.) (microscopic photo $40 \mathrm{X}$ )

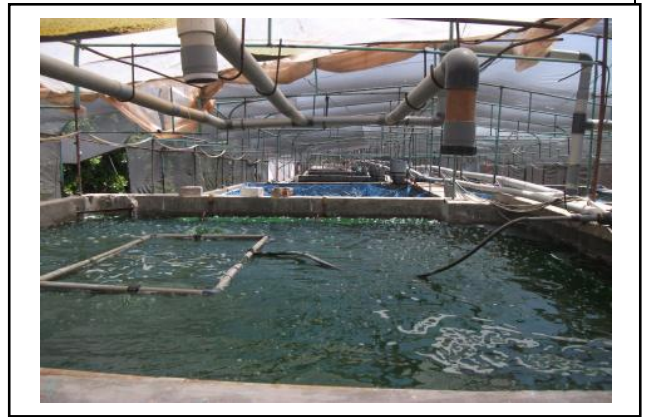

$25 \mathrm{~m}^{3}$
Plate 2 Manta 2 Water quality Sonde (Eureka)

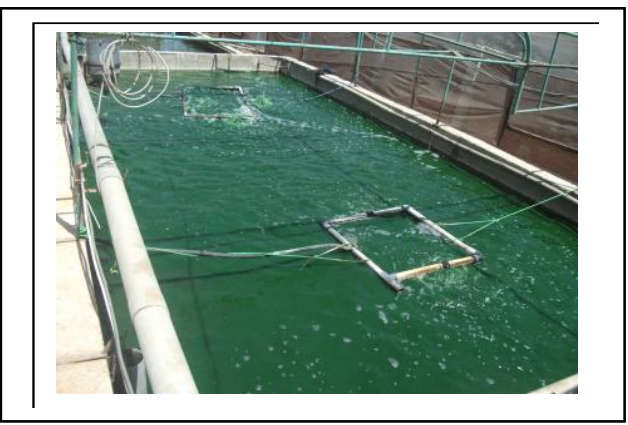

$50 \mathrm{~m}^{3}$

Plates (3 and 4): Cultivation of S.platensis on modified Zarrouk Medium in concrete ponds $25 \mathrm{~m}^{3}$ and $50 \mathrm{~m}^{3}$
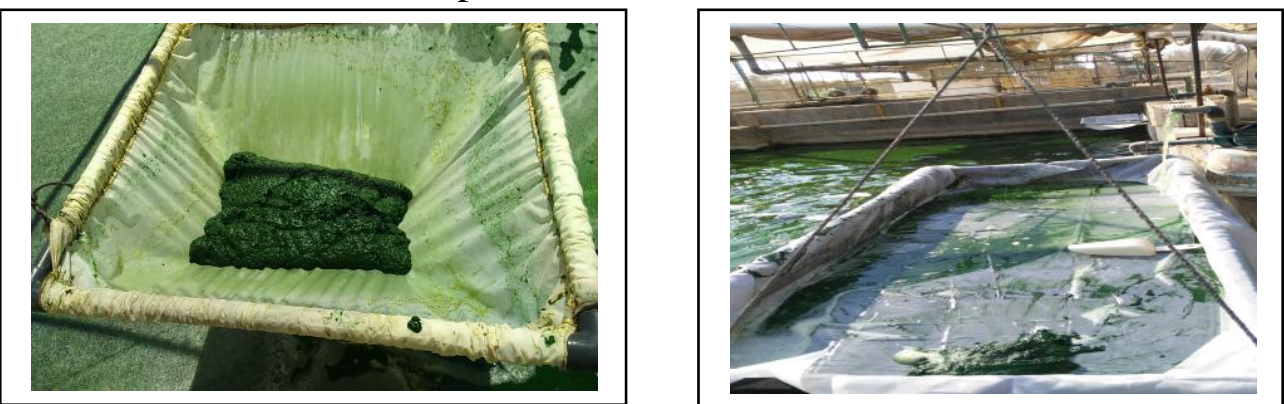

plates (5 and 6): The Harvested S. platensis from pond by 20 um mesh diameter plankton cloth 
J. Environ. Sci.

Institute of Environmental Studies and Research - AinShamsUniversity

\section{CONCLUSIONS AND RECOMMONDATIONS}

From the present study the biochemical contents for S. platensis were the best in oven dry $120{ }^{\circ} \mathrm{C}$ for large scale production however it is difficult to be applied in a small scale (field or aquaculture production), so open air drying is effective and available procedure in field and aquacultures where some precautions must be done.

1- Direct open air drying must be very quick otherwise the chlorophyll a will be destroyed and the dry product will appear bluish

2- The drying process at $120{ }^{\circ} \mathrm{C}$ is method saving time for drying Spirulina platensis, and saving the biochemical contents.

3- The total duration of drying should not exceed few hours and drying temperature should be limited up to $120^{\circ} \mathrm{C}$

4- Spirulina is a good replacer source of protein in aquafeed culture.

\section{REFERENCES}

A.O.A.C. (1980): Official method analysis. Association of official analytical chemists, 12th Ed. Washington D.C. USA

A.O.A.C. (1984): Official method analysis. Association of official analytical chemists, Helrich 7th Ed. Washington 4 D.C. USA

A.O.A.C. (2000): Official method of Analysis AOAC international No. 994.12. Chapter 4, P.18-19.19 ${ }^{\text {th }}$ Edition.

Abou El-kheir, W.S.; Ibrahim, E.A.; Taha, O.E. \& Abeer, M.A.(2002): Spirulina platensis ( blue green alga) and its food value to fish fry. J. Union Arab Biology, vol 10(B), pp 57-75

Abou El-kheir, W.S.; Ibrahim, E.A.; Helal A.M.(2008): Large- Scale Production of economically important cyanobacterium (Spirulina 
platensis) by using commercial fertilizers. Journal of Environmental Science Volume (17), No. 3

Aji, P. \& Mohamad, D. (2012): Drying Spirulina with Foam Mat Drying at medium temperature Internat. J. of Sci. and Eng. Vol. 3(2) 1-3

Aly, M.S. (2000) Ecological studies on phytoplankton in closed lakes of Wadi El-Natroun. Egyptian Journal of Phycology .v1, pp. 203210

Costa, J.A.V.; Gozza, K.L.; Olivveira, L. \& Magagnin,-G. (2001): Different nitrogen sources and growth responses of Spirulina platensis in microenvironments. World Journal of microbiology and biotechnology Vol. 17, no. 5, pp. 439-442.

Dernekbasi S.; Hatice U.; Ismihan K. \& Orhan A.(2010): Effect of dietary supplementation of different rates of Spirulina platensis on growth and feed conversion in Guppy ( Poecilia reticulate peters, 1860) Journal of Animal and veterinary advances. Vol. 9 pp 1395-1399

Dillon, J.C. \& Phan, P.A. (1993): Spirulina as a source of protein in human nutrition. Bulletin de l'institute Oceanographique, Monaco pp. 103-107

Dubois, M.; Gilles, K.A.; Hmilton, K.; Repers, P.A. \& Smith, F. (1993): Colorimetric method of determination of sugars and related substances. Analyt. Chem., vol. 18, pp. 350-356

El-Gamal, M.A.H. (1998): Production of protein and biomass by microalgae using organic wastes . 1998,Thesis ; M.Sc. ; Botany Cairo University , Faculty of Science pp 125-139

Feng, D. \& WU Z. (2006): Culture of Spirulina platensis in human urine for biomass production and $\mathrm{O} 2$ evolution. Journal of Zhejiang University Science B (1): 34-37

Fox, R.D. (1999): Third millennium aquaculture. Farming the micro-ocean. Marine cyanobacteria Charpy, Monaco, no. NS19, pp. 547-563

Goldstein, B.(1986): Survival and growth of 'Spirulina sp. in the saline ground waters of New Mexico, November $76 \mathrm{pp}$ 
Guo, Y. (2012) Effects of different drying processes on the quality of Spirulina platensis. Beijing forestry university, master's thesis.

Hanel, R.; Broekman, D.; Graaf, S. \& Schnack, D. (2007): Partial replacement of fish meal by lyophilized powder of the micro algae Spirulina platensis in pacific white shrimp diets, The open Marine Biology Journal, 1: 1-5

Henson, R.H. (1990): Spirulina algae improves Japanese fish Feeds. Aquacult. -Mag. vol. 16, no. 6, pp. 38-43

Helene, D. \& Fabiola, H. (2004): Biochemical and physical criteria of Spirulina after different drying process .Proceedings of the 14th International Drying Symposium ( IDS) vol. B pp. 900-907

Hilal, K.Y. \& Özlem S. (2014): Production of Spirulina platensis by adding sodium bicarbonate and urea into chicken manure medium. African Journal of Biotechnology Vol.13(14), pp. 1597-1603

Jenny, C.C.; Chan; Peter C.K.; Cheung; \& Put O.A. (1997): Comparative Studies on the Effect of Three Drying Methods on the Nutritional Composition of Seaweed Sargassum hemiphyllum. J. Agric. Food Chem.45(8), pp3056-3059

Jorge, A.V.C.; Luciane, M.C. \& Paul, D.F. (2003): Spirulina platensis growth in open raceway pons using fresh water supplemented with Carbon, Nitrogen and metal ions Z. Naturforsch 58c, 76-80

Kelly, M.; Bob, C. \& Gerald, R.C. (2011): Spirulina Nature's Superfood Cyanotech Corporation $3^{\text {rd }}$ edition $4-12$

Mepham, H. (1997). Spirulina - pondweed or protein-feed Feed-Mix.; $5(2): 32-34$

Nakagawa, H. \& Montgomery, W.L.(2007): Dietary supplements for the health and quality of cultured fish. CABA publishing, Cambridge, 133-167

Sandeep K. P.; Shukla S.P.; Venila A.; Purshothaman C.S.; Manjulekshmi N. (2015): Cultivation of Spirulina (Arthrospira) platensis in low cost sea water based media for extraction of value added 
pigments. Indian journal of Geo-Marine science. Vol. 44(3) March 2015

Shabana, K.A. \& Arabi M. S. (2012): Spirulina - an overview International Journal of Pharmacy and Pharmaceutical Sciences Vol 4, Issue 3, 2012

Siegelman, H. \& Kycia, J.(1978): Algal bili-proteins: Handbook of phycological method. Cambridge University Press, Cambridge, 71-79.

Srada, R.; Manoj, G.P. \& Ravishankar, G.A.(1999): Phycocyanin from Spirulina sp: influence of processing of biomass on phycocyanin yield, analysis of efficacy of extraction methods and stability studies on Phycocyanin. Process Biochemistry 34. 795-801

Soletto, D.; Binaghi, L.; Lodi, A.; Carvalho, J.C.M. \& Onverti, A. (2004): Batch and fed-batch cultivations of Spirulina platensis using ammonium sulphate and urea as nitrogen sources. Aquaculture-; 243(1/4): 217-224

Tiburcio, P.C. (2007): Optimization of low-cost drying methods to minimize lipid peroxidation in Spirulina platensis grown in the Philippines. Journal of Applied Phycology-: 19(6):719-726.

Tongsiri, S.; Mang-Amphan, K. \& Peerapornpisal, Y. (2010): Effect of Replacing Fishmeal with Spirulina on Growth, Carcass Composition and Pigment of the Mekong Giant Catfish. Asian Journal of Agricultural sciences Vol. 2 , (3) pp106-110

Vonshake, A.(1997): Spirulina Platensis ( Arthrospira): Physiology, cell biology and biotechnology. Journal of Applied Phycology June 1997, Volume 9, Issue 3, pp 295-296

Wanida, P.; Wareerat, K.; Siriluck, 1. \& Janpen, S. (2014): C-phycocyanin extraction from Spirulina platensis oven - dried biomass. The 26th annual meeting of the thai Society for Biotechnology and international conferences. 
Zarrouk, C.(1966): Contribution a Letude d une Cyanophycee. Influence de divers facteurs physiques et chimiques sur la croissance et la photosynthese de Spirulina maxima Thesis, University of Paris.

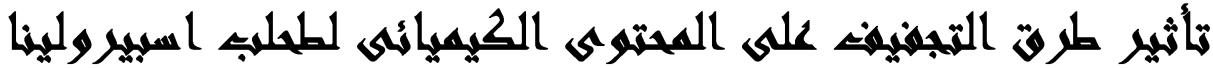

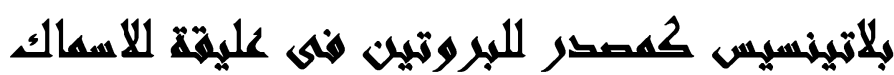

[1]

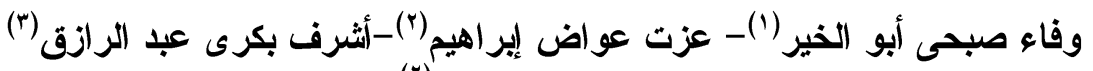

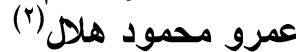

() كليه البنات، جامعة عين شمس r ) المعهد القومى لعلوم البحار و المصايد r) كليه الزراعة،

جامعة عين شمس البنات جامع

\section{المستخلص}

يهدف البحث الحالى الى دراسة تاثير درجات الحرارة على المحتوى الكيميائى لطحلب

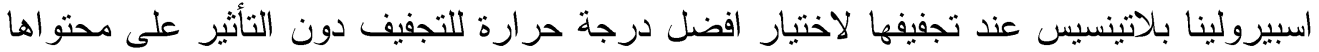

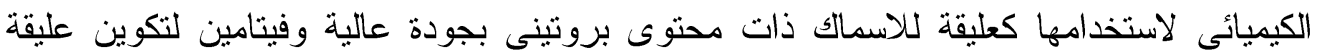
اسماك بجودة عالية و تكلفة أقل من العلائق التجارية الأخرى لتعطى انتاجا أفضل ومناعة ل ل لاسماك.

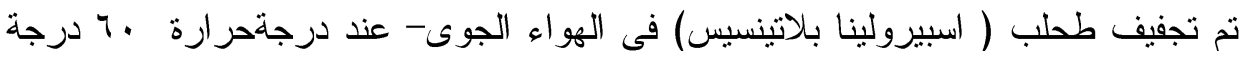

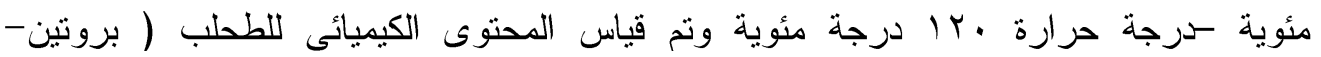

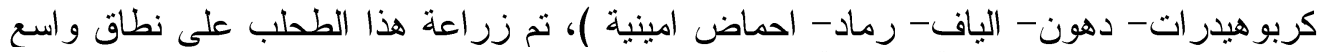

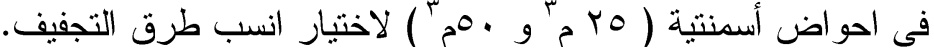

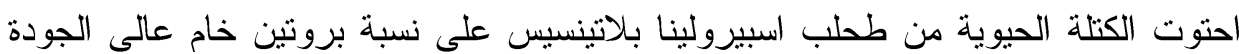

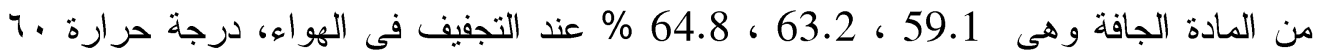

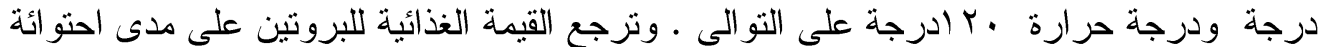

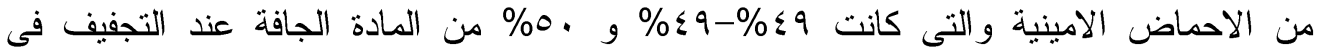

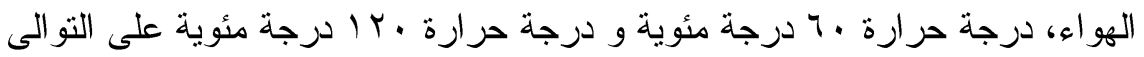

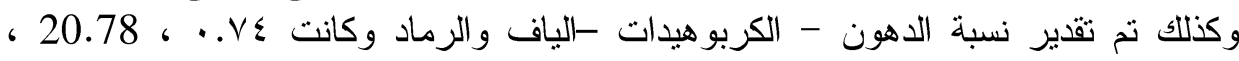

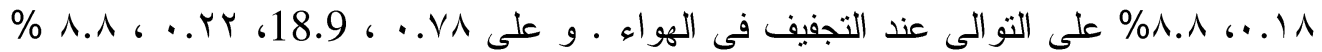




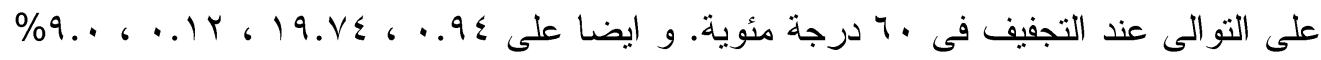

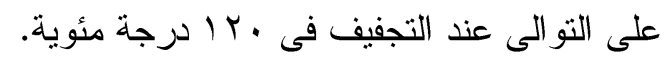

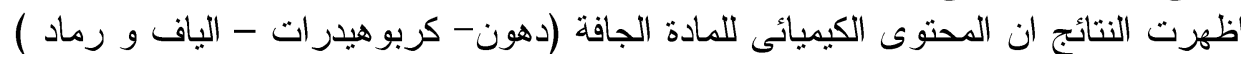

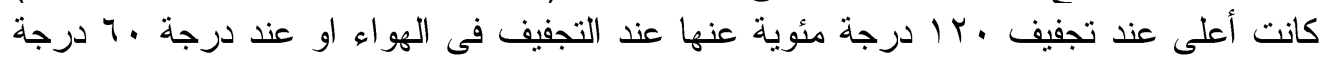

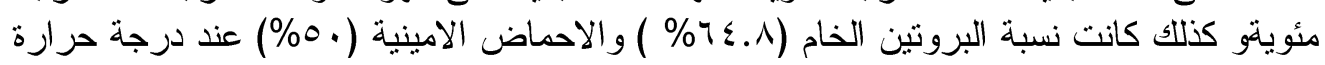

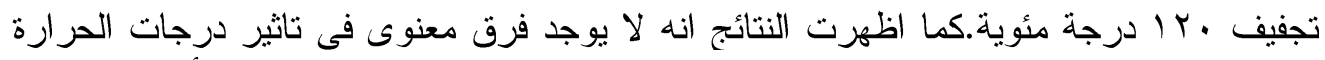

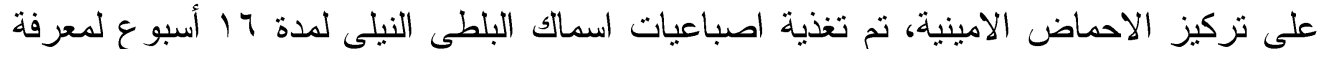

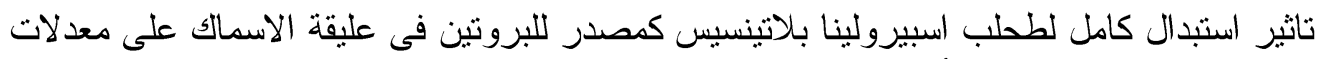

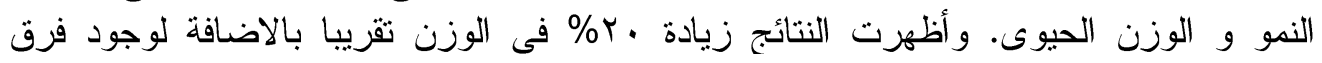

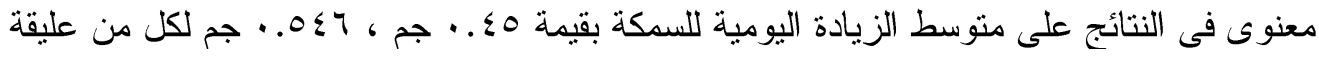

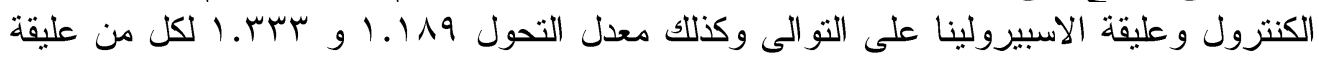

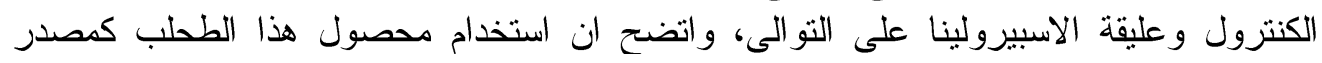
للبروتين فى عليقة الاسماك يوفر الحماية للبيئة المائية. 